JURNAL ILMIAH MANAJEMEN BISNIS DAN INOVASI UNIVERSITAS SAM RATULANGI

\title{
FAKTOR-FAKTOR YANG MEMPENGARUHI KINERJA PEGAWAI DIMEDIASI OLEH VARIABEL KEPUASAN KERJA PADA ERA $N E W$ NORMAL DI DINAS PERINDUSTRIAN DAN TENAGA KERJA KABUPATEN BADUNG
}

\author{
Ida Bagus Agung Andi Bhisma Manuaba, Ni Putu Nina Eka Lestari
}

Universitas Pendidikan Nasional A R T I C L E I N F O

\section{Keywords:}

work environment, New culture organization, digital leadership, job satisfaction, employee performance, Structural Equation Modeling
Kata kunci : lingkungan kerja, New culture organization, digital leadership, kepuasan kerja, kinerja pegawai, Structural Equation Modellin

Corresponding author:

Ida Bagus Agung Andi Bhisma Manuaba bhisma.bbm@gmail.com
Abstract: The aims of this study is to examine the influence of the work environment, new culture organization on employee performance mediated by employee job satisfaction. The number of respondents used in this study were as many as 145 respondents, all respondents were employees of the industry and labor office of the city of Bandung. The research data were obtained through distributing questionnaires and analyzed using the Structural Equation Modeling analysis technique with the help of the AMOS version 22 program. Based on the results of the analysis in this study, it is found that the work environment, New culture organization and digital leadership are factors that directly affect employee job satisfaction and employee performance. The results of this study also indicate that employee job satisfaction can mediate the indirect influence of the work environment, New culture organization and digital leadership on employee performance. Work environment, New culture organization and digital leadership will increase employee job satisfaction which in turn will increase employee performance.

Abstrak: Penelitian ini bertujuan untuk menguji pengaruh lingkungan kerja, new culture organization terhadap kinerja pegawai dengan dimediasi oleh kepuasan kerja pegawai. Jumlah responden yang digunakan dalam penelitian ini adalah sebanyak 145 responden, seluruh responden merupakan pegawai di dinas perindustrian dan tenaga kerja kota Bandung. Data hasil penelitian diperoleh melalui penyebaran kuesioner dan dianalisis dengan menggunakan teknik analisis Structural Equation Modelling dengan bantuan program AMOS versi 22. Berdasarkan hasil analisis dalam penelitian ini, diperoleh hasil bahwa lingkungan kerja, New culture organization dan digital leadership merupakan faktor - faktor yang secara langsung berpengaruh terhadap kepuasan kerja pegawai dan kinerja pegawai. Hasil penelitian ini juga menunjukkan bahwa kepuasan kerja pegawai dapat memediasi pengaruh tidak langsung lingkungan kerja, New culture organization dan digital leadership terhadap kinerja pegawai. Lingkungan kerja, New culture organization dan digital leadership akan meningkatkan kepuasan kerja pegawai yang selanjutnya akan meningkatkan kienrja pegawai 


\section{PENDAHULUAN}

Berbicara mengenai pegawai pemerintah di Indonesia sering berkisar pada profesionalisme, tingkat kesejahteraan, distribusi dan komposisi yang belum ideal, penempatan dalam jabatan yang belum didasarkan pada kompetensi, penilaian kinerja yang belum objektif, kenaikan pangkat yang belum didasarkan pada prestasi kerja, budaya kerja dan ethos kerja yang masih rendah dan penerapan peraturan disiplin yang tidak dilaksanakan secara konsisten. Daya Kerja dilingkungan instansi pemerintah terlihat sangat rendah, hali ini dapat dilihat dari jumlah jam kerja dan jam istirahat yang tidak sesuai dengan ketentuan. Penerapan jam kerja yang tidak teratur itulah yang menyebabkan kinerja seorang karyawan tidak bisa optimal. Ada anggapan bahwa bekerja di peusahaan pemerintah terkesan lebih banyak waktu luang dan beban kerja sedikit. Karena opini inilahmengapa kinerja pemerintahan sering mendapatkan kritik dari masyarakat karena kinerjanya yang masih rendah Beberapa hal tersebut merupakan masalah yang cukup menarik dan penting, karena bermanfaat bagi kepentingan individu, masyarakat, bangsa dan negara. Dengan demikian

Kinerja pegawai pemerintah sangat penting, karena bertujuan untuk memberikan pelayanan publik yang mendahulukan kepentingan umum, mempermudah urusan publik, mempersingkat pelayanan dan memberikan kepuasan kepada publik. Kinerja pegawai pemerintah, ada saatnya mengalami peningkatan dan penurunan. Untuk mengatasi permasalahan tersebut, terdapat beberapa upaya yang dapat dilakukan dalam peningkatan kinerja pegawai di instansi pemerintah yaitu dengan memperhatikan faktor-faktor yang mempengaruhi kinerja pegawai. Beberapa faktor yang mempengaruhi antara lain gaya kepemimpinan digital, lingkungan kerja, budaya organisasi yang dimediasi dengan kepuasan kerja pegawainya khususnya pada Dinas Perindustrian dan Tenaga Kerja Kabupaten Badung

Dinas Perindustrian dan Tenaga Kerja adalah Dinas yang sangat berpengaruh dengan sektor industri dan membantu mengurangi pengangangguran di Kabupaten badung. Kinerja pegawai di Dinas Perindustrian dan Tenaga Kerja Kabupaten Badung selalu perpatokan pada visi misi yang ada. Pengukuran penilaian kinerja PNS akan dinilai berdasarkan 2 (dua) unsur penilaian, yaitu :

1. SKP (Sasaran Kinerja Pegawai), yaitu : rencana kerja dan target yang akan dicapai oleh seorang PNS dan

2. Perilaku Kerja, yaitu : setiap tingkah laku, sikap atau tindakan yang dilakukan oleh PNS atau tidak melakukan sesuatu yang seharusnya dilakukan sesuai dengan ketentuan peraturan perundang-undangan.

Peraturan Pemerintah Nomor 46 Tahun 2011 tentang Penilaian Prestasi Kerja Pegawai Negeri Sipil mensyaratkan setiap PNS wajib menyusun SKP berdasarkan rencana kerja tahunan instansi. SKP itu memuat kegiatan tugas jabatan dan target yang harus dicapai dalam kurun waktu penilaian yang bersifat nyata dan dapat diukur. Penilaian prestasi kerja dengan menggunakan SKP ini mulai diberlakukan setiap instansi pemerintahan pada Tahun 2014 sesuai dengan Peraturan Pemerintah No.46 Tahun 2011. Dari unsur-unsur di atas yang mana pada saat penilaian dicocokkan dengan standar nilai yang ada di bawah ini. Peraturan Pemerintah ini mensyaratkan setiap PNS wajib menyusun SKP berdasarkan rencana kerja jangka pendek, jangka menengah dan jangka panjang. Berdasarkan pengamatan awal penelitian, diindikasikan terdapat masalah pada kinerja pegawai di instansi tersebut. Hal ini bisa dilihat dari rata-rata daftar penilaian Sasaran Kinerja Pegawai Negeri Sipil (SKP) jangka panjang yakni periode 2018-2019 Dalam menjalankan kinerjanya agar tetap sesuai peraturan pegawainya haruslah bagus di tahun berikutnya. Sesuai pernyataan Sedarmayanti (2012) apabila pegawai merasa puas dengan hasil kerjanya maka kinerjanya pun akan meningkat. 
Pada era New Normal pada ini banyak perubahan-perubahan yang terjadi pada pelayanan publik contohnya pada lingkungan kerja dengan syarat mematuhi protokol kesehatan yakni selalu memakai masker, menjaga jarak minimal 1 meter, dan peraturan jumlah pekerja minimal $25 \%$ dari jumlah pegawai pada masing-masing bidang. Pada era new normal ini juga pempimpin dituntut agar cara kepemimpinannya agar lebih fleksibel dan lebihn memanfaatkan teknologi digital membagi waktu untuk menjalankan strategi-strategi yang akan dikembangkan pada Dinas yang bersangkutan. Dan yang terakhir faktor Budaya Organisasi yang sudah pasti berubah menjadi new culture organization. Pada prinsipnya ada 2 elemen budaya organisasi. Pertama, elemen idealistik yang berupa keyakinan seperti asumsi dasar dan nilai-nilai yang menjadi pedoman dalam berperilaku. Kedua elemen yang bersifat behavioral yang tampak dan mudah diamati sepertihalnya artefak yang berwujud fisik, perilaku, dan verbal. Usut punya usut, setelah dilanda wabah pandemi Covid-19 ada organisasi yang fakum dan menunda sementara program-programnya. Disisi lain, justru ada juga yang memanfaatkan momen ini sebagai sarana komunikasi virtual agar lebih efektif yang memulai kebiasaan baru dengan hidup berdamingan dengan teknologi yang sudah disediakan agar tetap mematuhi protokol kesehatan lebih banyak melakukan Webinar seperti memakai aplikasi "ZOOM Meeting". Karena hal ini akan menentukan secara langsung maupun tidak langsung dalam mewujudkan visi dan misi yang akan dicapai. Berdasarkan uraian di atas, penulis mengkajinya dalam bentuk penelitian dengan memfokuskan pada masalah.

Penelitian ini bertujuan untuk menganalisis pengaruh lingkungan kerja, new culture organization dan digital leadership terhadap kinerja pegawai dimediasi oleh kepuasan kerja pada era new normal di Dinas Perindustrian dan Tenaga Kerja Kabupaten Badung. Kerangka konseptual digunakan untuk menjelaskan rangkaian hubungan antara variabel bebas lingkungan kerja, new culture organization dan digital leadership terhadap variabel terikat kepuasan kerja dan kinerja pegawai.

\section{KAJIAN PUSTAKA}

Nitisemito (2004), menyatakan faktor lain yang mempengaruhi kinerja dan kepuasan kerja pegawai dalam melaksanakan tugas adalah lingkungan kerja yaitu segala sesuatu yang ada di sekitar pekerja, yang dapat mempengaruhi dirinya dalam menjalankan tugas. Sedarmayanti (2008), menyatakan faktor lingkungan kerja berupa kondisi fisik kantor yang meliputi penerangan, suhu udara, dan lain-lain yang mampu meningkatkan suasana kondusif dan semangat kerja serta berpengaruh terhadap kinerja pegawai. Lingkungan kerja yang tidak memuaskan dapat menurunkan semangat kerja dan akhirnya menurunkan produktifitas kerja pegawai.

Perubahan Budaya Organisasi Budaya sebagai falsafah, ideologi, nilai-nilai, anggapan, keyakinan, harapan, sikap dan juga norma dimiliki secara bersama dan mengikat oleh setiap organisasi. Aspek budaya organisasi digolongkan menjadi 3 bagian Schein (2010), diantaranya: Pertama, artefak yang berisi berbagai hal yang dapat dilihat, didengar, dan dirasakan ketika dijumpai. Secara garis besar, aspek ini adalah sesuatu yang paling mudah untuk dilihat dan dirasakan. Sebelum wabah Covid-19 datang ke Indonesia yang akhirnya mengubah aktivitas organisasi menjadi \#dirumahsaja. Alhasil semua kegiatan dapat dimaksimalkan dengan metode virtualisasi.

Digital Leadership mengacu pada kepemimpinan di era baru, yaitu era yang ditandai dengan perkembangan teknologi yang pesat. Kepemimpinan diperlukan untuk memperbaiki banyak masalah yang diciptakan oleh era digital. Menurut Edy Sutrisno : Kepemimpinan adalah gejala universal yang ada pada setiap kelompok manusia sebagai sebuah sistem sosial, mulai dari 
kelompok kecil yang terdiri dari beberapa orang sampai pada kelompok besar yang dinamakan bangsa.Sutrisno (2009) Menurut George R. Terry : Leadership is actvity of influencing people to strive willingly for mutual objectives. ( Kepemimpinan adalah keseluruhan kegiatan atau aktivitas untuk mempengaruhi kemauan orang lain untuk mencapai tujuan bersama. dalam Sedarmayanti (2007) Menurut S.P. Siagian Kepemimpinan merupakan inti manajemen karena kepemimpinan adalah motor penggerak bagi sumber daya manusia dan sumber daya alam lainnya.

Badeni (2013) mengemukakan kepuasan kerja adalah sikap seseorang terhadap pekerjaannya yang dapat berupa sikap positif atau negative, puas atau tidak puas. Sedangkan Siagian (2013) mengemukakan bahwa kepuasan kerja merupakan cara pandang seseorang baik yang bersikap positif maupun bersikap negatif tentang pekerjaannya.Colquit, LePine, Wesson dalam Wibowo (2014), mengemukakan bahwa kepuasan dari pekerjaan terdiri dari 8 macam kategori indikator yaitu: gaji, peluang promosi, atasan, rekan sekerja, pekerjaan itu sendiri, altruism, status, dan lingkungan kerja.Pada dasarnya kepuasan kerja bersifat individual, setiap individu akan memiliki tingkat kepuasan yang berbeda-beda sesuai dengan nilai-nilai yang berlaku pada dirinya. Hal ini ada karena perbedaan masing-masing individu tersebut, semakin banyak aspek dalam pekerjaan yang sesuai dengan keinginan individu tersebut, semakin tinggi pula tingkat kepuasan yang diperoleh, dan akan memperoleh tingkat kepuasan yang rendah jika terjadi sebaliknya.

Menurut Sinambela, et al (2012) mengemukakan bahwa kinerja pegawai didefinisikan sebagai kemampuan pegawai dalam melakukan sesuatu keahlian tertentu. Kinerja pegawai sangatlah perlu, sebab dengan kinerja ini akan diketahui seberapa jauh kemampuan pegawai dalam melaksanakan tugas yang dibebankan kepadanya. Untuk itu diperlukan penentuan kriteria yang jelas dan terukur serta ditetapkan secara bersama-sama yang dijadikan sebagai acuan.Menurut Wilson (2012) Kinerja adalah hasil pekerjaan yang dicapai seseorang berdasarkan persyaratan-persyaratan pekerjaan (Job requirement) Kinerja seorang pegawai merupakan kesuksesan yang ditunjukkan oleh seorang pegawai didalam dia melaksanakan tugas yang menjadi tanggung jawabnya. Kerangka konseptual penelitian ini adalah seperti dalam gambar 1.

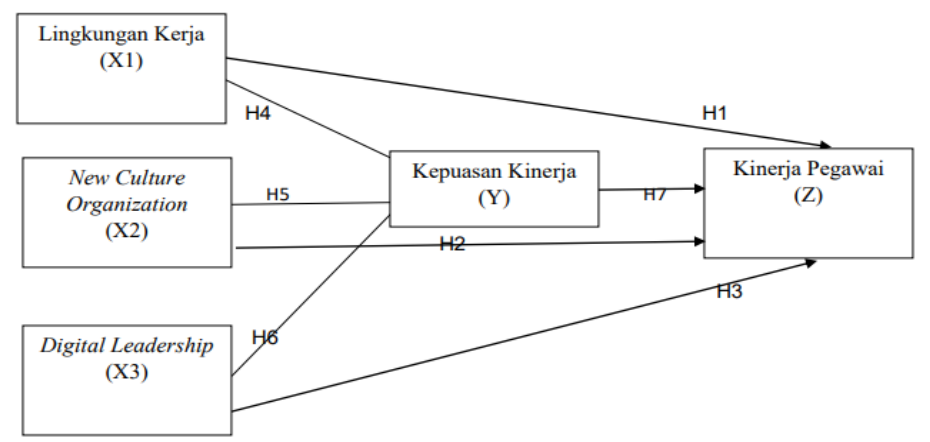

Gambar 1. Model Konseptual Penelitian

Arie Puspita Wardhani,dkk (2016) menyatakan bahwa Lingkungan berpengaruh secara signifikan terhadap Kinerja Pegawai (Studi kasus di Dinas Kebudayaan dan Pariwisata Kota Semarang). Menurut Emi Susanty (2017) menemukan bahwa Lingkingan berpengaruh secara signifikan terhadap kinerja pegawai (Studi kasus Dinas Pertambangan dan Energi Kabupaten Musi Banyuasin), Djuremi,dkk (2016) terdapat pengaruh yang positif dan signifikan antara Lingkungan Kerja terhadap Kinerja pegawai (Studi di Dinas Pasar Kota Semarang). H1 : Lingkungan Kerja berpengaruh positif terhadap Kinerja Pegawai 
Masril (2019) menyatakan bahwa Leadership berpengaruh signifikan terhadap kinerja pegawai (Studi kasus di dinas Energi dan Sumber Daya Mineral Provinsi Sumatra Barat), menurut Rochmad Fadjar Darmanto (2019) menyatakan bahwa Leadershi pberpengaruh nyata terhadap motivasi kerja pegawai (Studi kasus di Dinas Pemadam Kebakaran Kota Bekasi). Dan menurut Nazma Amalia (2013) menyatakan bahwa Leadership dalam satu unit organisasi berpengaruh positif dan signifikan terhadap kinerja pegawai (studi kasus di Dinas Pendapatan, Pengelolaan Keuangan dan Aset Kabupaten Barito Timur)

H2 : Leadership berpengaruh positif terhadap kinerja pegawai

Hasil penelitian Isnanindia Septi Putri (2016), menyatakan bahwa Budaya Organisasi berpengaruh positif dan signifikan terhadap Kinerja Pegawai diterima.(studi kasus di Dinas Pendidikan dan Kebudayaan Kota Samarinda), Menurut Latib,dll (2016) berarti budaya organisasi merupakan hal yang sangat penting dan berkaitan dengan komitmen organisasi. Menurut Ireyne P Dumanaw,dll (2018) Budaya Organisasi berpengaruh positif dan tidak signifikan terhadap Kinerja Pegawai (studi kasus Dinas Tenaga Kerja Kabupaten Minahasa Utara)

H3 : Budaya Organisasi berpengaruh positif terhadap kinerja pegawai

Hasil penelitian Aris Munandar (2019) menyatakan Lingkungan kerja berpengaruh positif terhadap kinerja pegawai DPMPTSP Aceh melalui kepuasan kerja sebagai variabel intervening (studi kasus di Dinas Penanaman Modal dan Pelayanan Terpadu Satu Pintu). Menurut Anita Setyarini Widya P, dll (2019) Lingkungan kerja berpengaruh signifikan terhadap kepuasan kerja pegawai (studi kasus di Dinas Peternakan dan Perikanan Kabupaten Bojonegoro ), menurut Achmad Jufri, dll (2018) Lingkungan kerja berpengaruh signifikan terhadap kepuasan kerja (studi kasus Dinas Koperasi dan Usaha Mikro Kabupaten Jombang) menurut Putri Burhani,dll (2018) Lingkungan kerja berpengaruh signifikan terhadap kepuasan kerja karyawan (studi kasus Dinas Kearsipan dan Perpustakaan Provinsi Sumatera Bara )

H4 : Lingkungan kerja berpengaruh positif terhadap Kepuasan kerja

Hasil penelitian Aliyas Mandri, dll (2018) Kepemimpinan berpengaruh positif dan signifikan terhadap kepuasan kerja (studi kasus di Dinas Pekerjaan Umum dan Penataan Ruang (PUTR) Kabuaten Rokan Holir. Menurut Anindita Dana Paramita, dll (2016) membuktikan bahwa variabel leadership berpengaruh signifikan positif terhadap variabel kepuasan kerja (studi kasus di Dinas PSDA dan ESDM Kota Semarang) . Menurut Racmat Suprianto Sinaga, dll (2017) Kepemimpinan berpengaruh positif dan signifikan terhadap kepuasan kerja (studi kasus di Dinas Pendidikan dan UPTD Dinas Pendidikan Kabupaten Indragiri Hulu)

H5 : Leadership berpengaruh positif terhadap kepuasan kerja

Made Dyah Ayu Pranita dan Ida Ayu Made Sasmita Dewi (2018) budaya organisasi berpengaruh positif dan signifikan terhadap kinerja pegawai melalui kepuasan kerja (studi kasus di Dinas Kesehatan Kabupaten Tabanan). Menurut Eny Widyastuti (2018) Budaya organisasi berpengaruh positif tidak signifikan terhadap kepuasan kerja pegawai (studi kasu di Dinas Perdagangan Tenaga Kerja Koperasi dan UKM Kabupaten Karanganyar). Menurut Stefanie Inggried Gorap budaya organisasi mempunyai pengaruh yang positif dan signifikan terhadap kepuasan kerja (studi kasus di Dinas Kesehatan Daerah Kota Tomohon) H6 : Budaya Organisasi berpengaruh positif terhadap kepuasan kerja 
Sukarjati, dll (2016) Kepuasan kerja berpengaruh positip dan signifikan terhadap kinerja pegawai (studi kasus di Dinas Pengelolaan Keuangan dan Aset Daerah Kota Semarang), Ida Respatiningsih (2015) terdapat pengaruh yang positif dan signifikan antara kepuasan kerja terhadap kinerja pegawai (studi kasus di Inspektorat Kabupaten Pemalang), Selvia Nanta Maharani (2016)

H7 : Kepusan kerja berpengaruh positif terhadap Kinerja pegawai

\section{METODE PENELITIAN}

Lokasi penelitian dilakukan di Dinas Perindustrian dan Tenaga Kerja Kabupaten Badung. Peneliti memilih lokasi ini karena tertarik untuk mengetahui bagaimana respon dari pegawai di Dinas Perindustrian dan Tenaga Kerja Kabupaten Badung mengenai bagaimana kinerja pegawai dengan faktor lingkungan kerja, New Culture Organization, Digital Leadership seorang pempimpin (Kasi, Kabid, Kadis) serta dimediasi dengan kepuasan kinerja

Dalam penelitian ini yang menjadi populasi adalah seluruh Pegawai di Dinas Perindustrian dan Tenaga Kerja Kabupaten Badung Tahun 2019. Populasi dalam penelitian ini adalah semua pegawai Dinas Perindustrian dan Tenaga Kerja sebanyak 145 orang Pegawai. Teknik yang digunakan dalam pengambilan sampel adalah total sampling yaitu pengambilan sampel seluruh pegawai pada Dinas Perindustrian dan Tenaga Kerja

SEM menggunakan pendekatan konfirmasi yang memiliki aspek penting yaitu: proses yang dikaji ditampilkan dalam bentuk persamaan struktural (regresi) dan korelasi struktural dari persamaan yang dapat dibuat secara visual, sehingga memudahkan konseptual suatu teori yang akan dikaji. Digunakannya metode SEM dalam penelitian ini, karena SEM memungkinkan dapat menjawab pertanyaan penelitian yang bersifat regresif maupun dimensional, Yaitu dapat mengukur dimensi dimensi dari sebuah konsep.

\section{HASIL PENELITIAN DAN PEMBAHASAN}

Dalam penelitian ini, pengaruh lingkungan kerja, new culture organization dan digital leadership terhadap kinerja pegawai dengan dimediasi oleh kepuasan kerja akan dianalisis dengan menggunakan analisis SEM. Tahap - tahap dalam analisis SEM meliputi tahap pengujian model peengukuran (Confirmatory Factor Analysis), tahap uji asumsi SEM, tahap uji Goodness of fit model dan tahap pengujian model strukural.

\section{Pengujian Model Pengukuran Analisis CFA}

Terdapat 3 variabel eksogen, yaitu variabel sikap lingkungan kerja, new culture organization dan digital leadership yang masing-masing diukur dengan 5 indikator sehingga spesifikasi model pengukuran untuk konstruk eksogen akan berbentuk seperti berikut : 


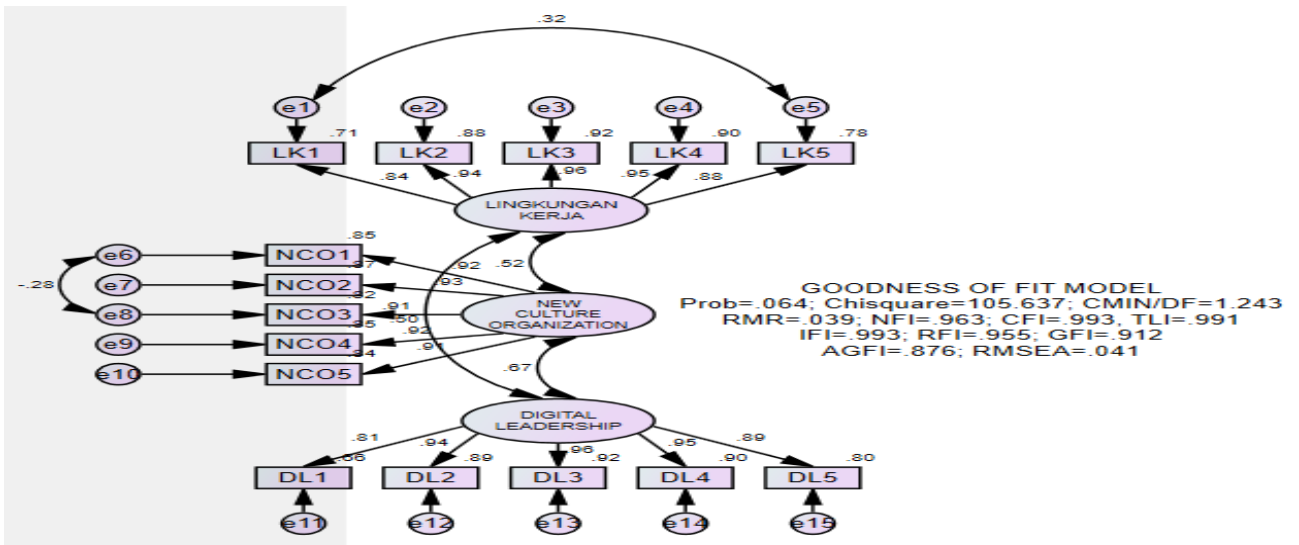

Gambar 2. Spesifikasi Model Pengukuran Konstruk Eksogen dan hasil pengujian goodness of fit

Berdasarkan hasil pengujian goodness of fit model pada model pengukuran konstruk eksogen di atas, dapat dilihat bahwa model pengukuran konsturk eksogen telah memenuhi kriteria goodness of fit model yang baik (probablity chi square model sebesar 0,064, sehingga layak digunakan untuk menguji validitas dan reliabilitas seluruh indikator dalam konstruk eksogen.

Validitas konstruk dalam analisis SEM dapat dilakukan dengan melihat nilai Loading factor masing-masing indikator dalam konstruk, sedangkan reliabilitas konstruk dapat dilkukan dengan melihat nilai AVE dan CR masing-masing konstruk.

Pengujian validitas dan reliabilita skonstruk ini,indikator dinyatakan valid jika memiliki nilai Loading factor $>0,5$, selanjutnya konstruk dinyatakan reliabel jika AVE model $>0,5$ dan CR model $>0,7$. Berikut ini adalah hasil uji validitas dan reliabilitas konstruk berdasarkan nilai loading factor dan perhitungan nilai CR dan AVE masing-masing konstruk :

Tabel 1. Hasil Uji Validitas dan Reliabilitas Konstruk Eksogen

\begin{tabular}{|c|c|c|c|c|c|c|}
\hline Variebel & Indikator & $\lambda$ & Validitas & AVE & $\mathbf{C R}$ & Reliabilitas \\
\hline \multirow{5}{*}{$\begin{array}{c}\text { Lingkungan } \\
\text { Kerja }\end{array}$} & LK1 & 0.840 & valid & \multirow[t]{5}{*}{0.836} & \multirow[t]{5}{*}{0.954} & \multirow[t]{5}{*}{ reliabel } \\
\hline & LK2 & 0.937 & valid & & & \\
\hline & LK3 & 0.961 & valid & & & \\
\hline & LK4 & 0.948 & valid & & & \\
\hline & LK5 & 0.881 & valid & & & \\
\hline \multirow{5}{*}{$\begin{array}{l}\text { New Culture } \\
\text { Organization }\end{array}$} & $\mathrm{NCO} 5$ & 0.915 & valid & \multirow[t]{5}{*}{0.846} & \multirow[t]{5}{*}{0.955} & \multirow[t]{5}{*}{ reliabel } \\
\hline & $\mathrm{NCO} 4$ & 0.925 & valid & & & \\
\hline & $\mathrm{NCO} 3$ & 0.906 & valid & & & \\
\hline & $\mathrm{NCO} 2$ & 0.933 & valid & & & \\
\hline & $\mathrm{NCO} 1$ & 0.921 & valid & & & \\
\hline \multirow{5}{*}{$\begin{array}{c}\text { Digital } \\
\text { Leadership }\end{array}$} & DL5 & 0.892 & valid & \multirow[t]{5}{*}{0.834} & \multirow[t]{5}{*}{0.954} & \multirow[t]{5}{*}{ reliabel } \\
\hline & DL4 & 0.951 & valid & & & \\
\hline & DL3 & 0.960 & valid & & & \\
\hline & DL2 & 0.944 & valid & & & \\
\hline & DL1 & 0.811 & valid & & & \\
\hline
\end{tabular}

Sumber : Hasil pengolahan data (2020) pada Lampiran 
Berdasarkan hasil uji validitas dan reliabilitas konstruk pada tabel di atas, hasil analisis menunjukkan bahwa seluruh indikator pada konstruk eksogen valid dalam mengukur konstruknya karena telah memiliki loading factor $>0,5$. Selanjutnya hasil analisis juga menunjukkan bahwa seluruh konstruk eksogen telah reliabel karena telah memiliki nilai $\mathrm{CR}>0,7$ dan AVE $>0,5$. Terdapat 2 variabel endogen, yaitu variabel kepuasan kerja yang diukur dengan 5 indikator dan kinerja pegawai yang diukur dengan 3 indikator sehingga spesifikasi model pengukuran untuk konstruk endogen akan berbentuk seperti berikut :

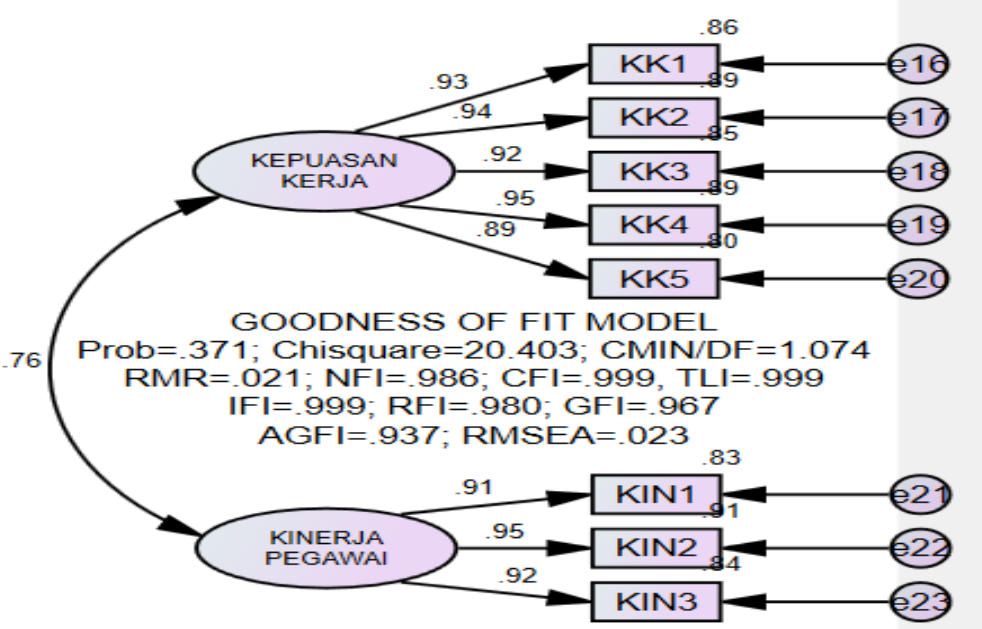

\section{Gambar 3. Spesifikasi Model Pengukuran Konstruk Endogen dan hasil pengujian goodness of fit}

Berdasarkan hasil pengujian goodness of fit pada model pengukuran konstruk endogen di atas, dapat dilihat bahwa model pengukuran konstruk endogen telah memenuhi kriteria goodness of fit yang baik dengan probabilitas chi square sebesar 0,371, sehingga model ini layak digunakan untuk menguji validitas dan reliabilitas seluruh indikator pada konstruk endogen. Sebagaimana pengujian validitas dan reliabilitas konstruk sebelumnya pada konstruk eksogen, maka dalam pengujian ini indikator dinyatakan valid jika memiliki nilai Loading factor $>0,5$, selanjutnya konstruk dinyatakan reliabel jika AVE model $>0,5$ dan CR model $>0,7$. Berikut ini adalah hasil uji validitas dan reliabilitas konstruk berdasarkan nilai loading factor dan perhitungan nilai CR dan AVE masing-masing konstruk :

Tabel 2. Hasil Uji Validitas dan Reliabilitas Konstruk

\begin{tabular}{|c|c|c|c|c|c|c|}
\hline Variebel & Indikator & $\lambda$ & Validitas & AVE & CR & Reliabilitas \\
\hline \multirow{5}{*}{$\begin{array}{c}\text { Kepuasan } \\
\text { Kerja }\end{array}$} & KK1 & 0.927 & valid & \multirow[t]{5}{*}{0.857} & \multirow[t]{5}{*}{0.955} & \multirow[t]{5}{*}{ reliabel } \\
\hline & KK2 & 0.941 & valid & & & \\
\hline & KK3 & 0.923 & valid & & & \\
\hline & KK4 & 0.945 & valid & & & \\
\hline & KK5 & 0.893 & valid & & & \\
\hline \multirow{3}{*}{$\begin{array}{l}\text { Kinerja } \\
\text { Pegawai }\end{array}$} & KIN1 & 0.909 & valid & \multirow[t]{3}{*}{0.860} & \multirow[t]{3}{*}{0.886} & \multirow[t]{3}{*}{ reliabel } \\
\hline & KIN2 & 0.953 & valid & & & \\
\hline & KIN3 & 0.919 & valid & & & \\
\hline
\end{tabular}

Sumber : Data diolah (2020) pada Lampiran 
Berdasarkan hasil uji validitas dan reliabilitas konstruk pada tabel di atas, hasil analisis menunjukkan bahwa seluruh indikator pada masing-masing konstruk valid dalam mengukur konstruknya karena telah memiliki loading factor $>0,5$. Selanjutnya hasil analisis juga menunjukkan bahwa seluruh konstruk dalam model analisis SEM ini telah reliabel karena telah memiliki nilai $\mathrm{CR}>0,7$ dan $\mathrm{AVE}>0,5$.

\section{Uji Prasyarat Analisis SEM}

Ukuran sampel minimal untuk analisis SEM dengan metode estimasi Maximum Likelihood adalah 5-10 kali jumlah indikator Ghozali,2011:64. Jumlah indikator dalam model SEM ini adalah sebanyak 23 indikator, sehingga jumlah sampel yang diperlukan dalam analisis SEM ini paling tidak adalah sebanyak 115 - 230 sampel. Jumlah responden dalam penelitian ini adalah sebanyak 145 responden, oleh karena jumlah sampel telah memlebihi batas minima sampel SEM maka jumlah responden yang digunakan dalam penelitian ini dinyaakan cukup dan layak untuk dianalisis dengan menggunakan analisis SEM.

Outlier adalah observasi yang muncul dengan nilai-nilai ekstrim baik secara univariat maupun multivariat yang muncul karena kombinasi karakteristik unik yang dimilikinya dan terlihat sangat jauh berbeda dari observasi-observasi lainnya. Dalam analisis SEM, outlier dapat dideteksi dengan melihat tabel mehalonobis distance, dalam tabel tersebut data disebut sebagai outlier jika memiliki nilai Mahalanobis $d$-squared melebihi 49,728 yaitu nilai Chi Square pada derajat bebas 23 (karena ada 23 indikator valid yang dianalisis) dan taraf signifikan 0,001. Hasil deteksi outlier pada tabel berikut menunjukkan bahwa dari 145 data yang dianalisis tidak ada data yang memiliki jarak mahalonobis tertinggi hanya sebesar 36,229 dan tidak ada data dengan mahalonobis disntace di atas 40,728, hal ini menunjukkan bahwa tidak ada outlier dalam data yang dianalisis. Seluruh data dapat dianalisis dengan menggunakan analisis SEM.

Tabel 3. Deteksi Outlier dalam data SEM

\section{Observations farthest from the centroid (Mahalanobis distance) (Group number 1)}

\begin{tabular}{rrrr}
\hline Observation number & Mahalanobis d-squared & p1 & p2 \\
\hline $\mathbf{1 1 5}$ & 36.229 & .039 & .997 \\
$\mathbf{1}$ & 36.181 & .040 & .980 \\
$\mathbf{1 3 6}$ & 35.862 & .043 & .949 \\
$\ldots .$. & $\ldots$. & $\ldots$ & $\ldots$. \\
$\ldots .$. & $\ldots$. & $\ldots$. & $\ldots$. \\
$\mathbf{1 4 2}$ & 20.818 & .592 & .024 \\
$\mathbf{3 6}$ & 20.778 & .595 & .018 \\
$\mathbf{8}$ & 20.765 & .595 & .012 \\
\hline
\end{tabular}

Sumber : Data diolah (2020) pada Lampiran

\section{Uji Normalitas}

Uji Normalitas dalam analisis SEM dimaksudkan untuk mengetahui normal tidaknya distribusi penelitian masing-masing variabel. Evaluasi normalitas dilakukan dengan melihat nilai cr skewness atau kurtosis baik secara univariat maupun univariat, data dikatakan berdistribusi normal jika nilai cr skewness atau cr kurtosis di bawah harga mutlak 2,58 (Ghozali; 2016), 
sedangkan dalam Ferdinand (2006) nilai c.r multivariat di bawah 8 masih dapat diterima dan analisis masih dapat dilanjutkan asalkan seluruh indikator telah memiliki nilai c.r kurtosis $<$ dalam rentan $-2,58<\mathrm{z}<2,58$. Berikut ini adalah hasil uji normalitas data pada model:

Tabel 4. Hasil Uji Normalitas Assessment of normality (Group number 1)

\begin{tabular}{|l|rrrrrr|}
\hline Variable & min & max & skew & c.r. & kurtosis & c.r. \\
\hline KIN3 & 1.000 & 5.000 & -.491 & -2.412 & .003 & .006 \\
KIN2 & 1.000 & 5.000 & -.570 & -2.801 & -.105 & -.258 \\
KIN1 & 1.000 & 5.000 & -.653 & -3.211 & .147 & .360 \\
KK5 & 1.000 & 5.000 & -.649 & -3.190 & .037 & .090 \\
KK4 & 1.000 & 5.000 & -.663 & -3.260 & -.068 & -.166 \\
KK3 & 1.000 & 5.000 & -.668 & -3.282 & -.133 & -.327 \\
KK2 & 1.000 & 5.000 & -.619 & -3.044 & -.280 & -.688 \\
KK1 & 1.000 & 5.000 & -.638 & -3.139 & -.261 & -.642 \\
DL1 & 1.000 & 5.000 & -.660 & -3.246 & -.087 & -.215 \\
DL2 & 1.000 & 5.000 & -.512 & -2.516 & -.127 & -.312 \\
DL3 & 1.000 & 5.000 & -.599 & -2.945 & -.042 & -.104 \\
DL4 & 1.000 & 5.000 & -.535 & -2.628 & -.326 & -.802 \\
DL5 & 1.000 & 5.000 & -.408 & -2.007 & -.388 & -.955 \\
NCO1 & 1.000 & 5.000 & -.662 & -3.255 & .267 & .655 \\
NCO2 & 1.000 & 5.000 & -.614 & -3.016 & .069 & .168 \\
NCO3 & 1.000 & 5.000 & -.657 & -3.228 & -.033 & -.081 \\
NCO4 & 1.000 & 5.000 & -.759 & -3.730 & .253 & .621 \\
NCO5 & 1.000 & 5.000 & -.618 & -3.038 & -.209 & -.515 \\
LK5 & 1.000 & 5.000 & -.735 & -3.615 & .129 & .316 \\
LK4 & 1.000 & 5.000 & -.638 & -3.137 & -.016 & -.038 \\
LK3 & 1.000 & 5.000 & -.646 & -3.178 & -.030 & -.074 \\
LK2 & 1.000 & 5.000 & -.513 & -2.522 & -.192 & -.471 \\
LK1 & 1.000 & 5.000 & -.515 & -2.533 & -.209 & -.514 \\
Multivariate & & & & & 1.187 & .211 \\
\hline
\end{tabular}

Sumber : Data diolah (2020) pada Lampiran

Hasil uji normalitas menunjukkan bahwa data penelitian telah berdistribusi normal karena nilai kurtosis univariat seluruh indikator telah berada dalam interval $-2,58<\mathrm{z}<2,58$ begitu juga dengan nilai c.r multivariat sebesar 0,211 menunjukkan bahwa cr multivariat telah berada di dalam interval $-2,58<\mathrm{z}<2,58$, hal ini menunjukkan bahwa data yang akan dianalisis telah beridistribusi normal baik secara univariat maupun multivariat.

\section{Uji Multikolinearitas}

Uji multikolinearitas dalam analisis SEM dilakukan dengan melihat korelasi antar variabel eksogen. Model SEM dinyatakan tidak memuat multikolinearitas antar variabel eksogen jika nilai korelasi antar variabel eksogen tidak ada yang melebihi 0,9. Hasil analisis pada tabel di bawah ini menunjukkan bahwa korelasi antar variabel lingkungan kerja dengan new culture organization adalah sebesar 0,523, korelasi antar variabel new culture organization dengan digital leadership sebesar 0,670 dan korelasi antara lingkungan kerja dan digital leadership sebesar 0,318. Oleh 
karena korelasi antar variabel eksogen tidak ada yang melebihi 0,9 maka dinyatakan bahwa tidak terjadi multikolinearitas antar variabe eksogen dalam model SEM.

Tabel 5. Hasil Uji Multikolinearitas Correlations: (Group number 1 - Default model)

\begin{tabular}{|lll|r|}
\hline & & & Estimate \\
\hline LK & $<-->$ & NCO & .523 \\
NCO & $<-->$ & DL & .670 \\
LK & $<-->$ & DL & .499 \\
e1 & $<-->$ & e5 & .318 \\
\hline
\end{tabular}

Sumber : Data diolad 2020 pada Lampiran

\section{Pengujian Goodness of Fit Model Struktural}

Pengujian model struktural digunakan untuk menguji hipotesis penelitian. Tahap - tahap dalam pengujian model struktural meliputi tahap pembentukan model struktural, uji kelayakan model struktural dan uji signifikansi pengaruh variabel eksogen terhadap variabel endogen. Dengan mengacu pada hipotesis dan kerangkan model yang dibangun dalam penelitian ini maka spesifikasi model analisis SEM yang dibangun adalah sebagai berikut :

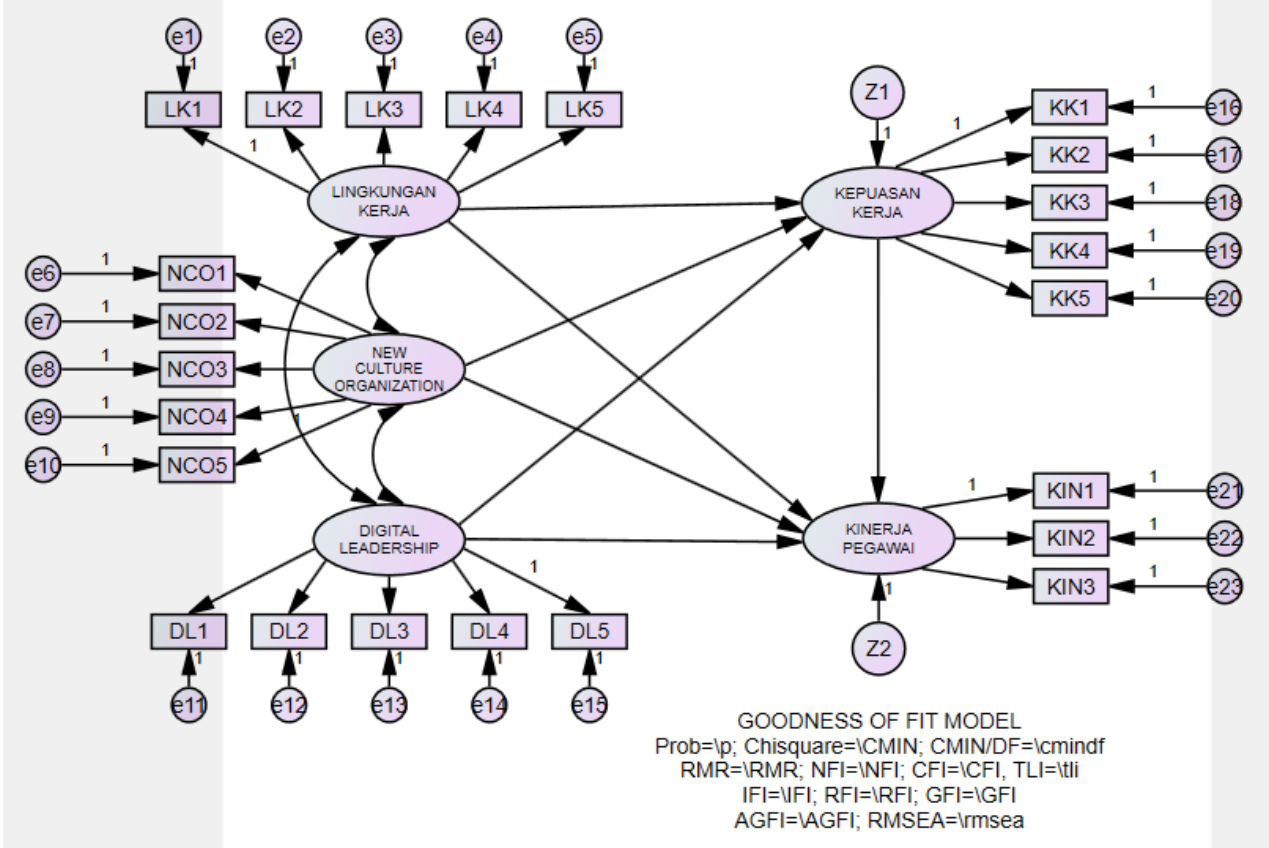

Gambar 5. Spesifikasi Model SEM

Uji kecocokan model struktural dalam analisis SEM dilakukan dengan melihat beberapa kriteria Goodness of fit model seperti nilai Chi Square, probabilitas, df, GFI, AGFI, TLI, CFI RMSEA dan RMR. Dalam penelitian ini, terpenuhinya goodness of fit model akan difokuskan pada indikator goodness of fit model yang berupa nilai probabilitas dan Chi Square model. Nilai probabilitas dan Chi square model yang tidak signifikan (probabilitas $>0,05$ dan Chi Square $<$ Chi Square (0,05,df model)) menunjukkan bahwa model SEM yang diestimasi dengan data yang 
dianalisis memiliki matriks kovarian yang sama dengan matriks kovarian populasi sehingag dipastikan dapat memberikan gambaran kondisi populasi yang sebenarnya

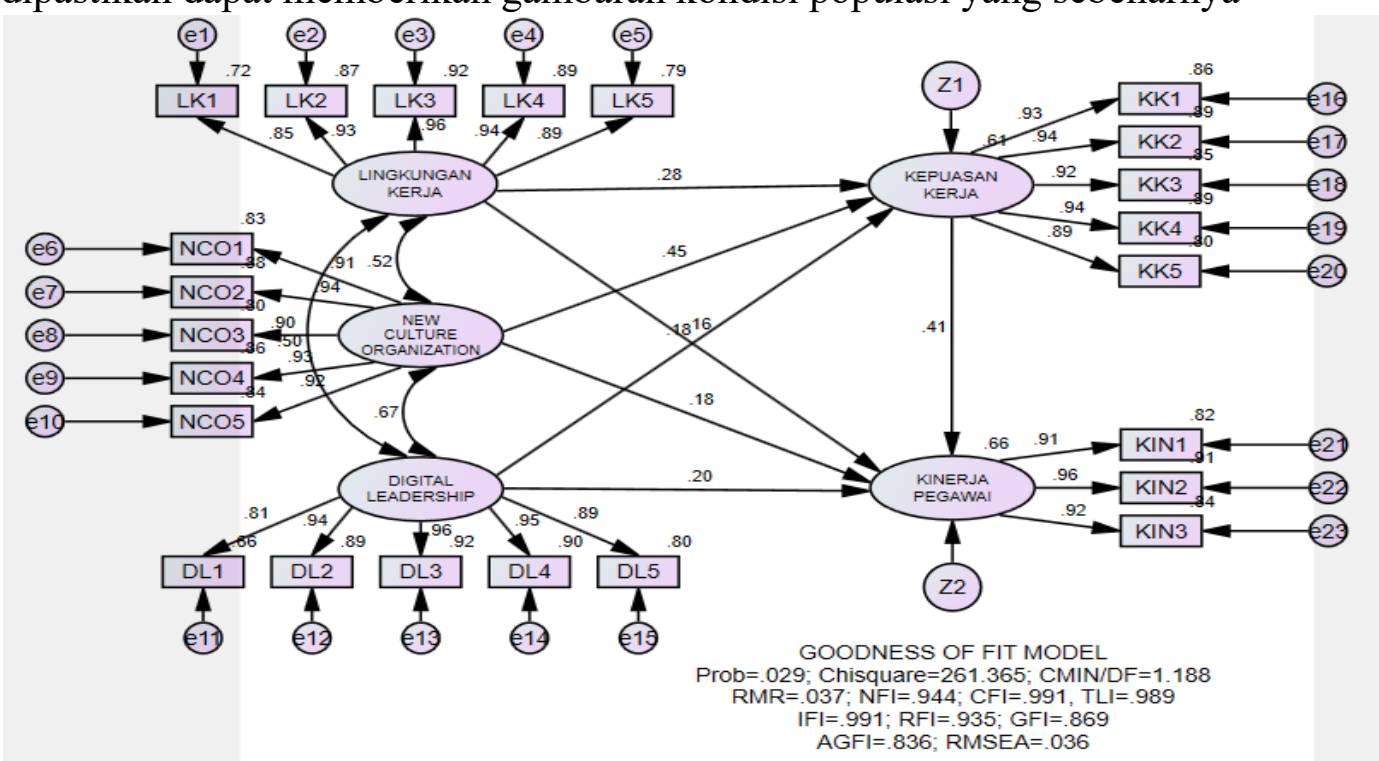

Gambar 6. Hasil Estimasi Model Struktural

Berdasarkan hasil estimasi model pada gambar di atas, nilai probability chi square masih di bawah 0,05 yaitu sebesar 0,029 yang berarti bahwa model belum memiliki matriks covarian yang sama dengan matriks covarian populasi sehingga belum dapat menunjukkan kondisi populasi yang sebenarnya. Untuk mengatasi hal tersebut, maka model perlu dimodifikasi dengan cara menghubungkan error indikator yang dapat menurunkan nilai Chi sqaure model dan meningkatkan probability chi square model sesuai dengan arahan AMOS dalam tabel modification indicase

Tabel 6. Modification Indicase Modification Indices (Group number 1 - Default model) Covariances: (Group number 1 - Default model)

\begin{tabular}{|c|c|c|c|c|}
\hline & & & M.I. & $\begin{array}{r}\text { Par } \\
\text { Change }\end{array}$ \\
\hline $\mathrm{e} 22$ & $<-->$ & Z1 & 5.295 & -.052 \\
\hline e17 & $<-->$ & LK & 6.874 & .062 \\
\hline el1 & $<-->$ & LK & 5.829 & .088 \\
\hline e13 & $<-->$ & e11 & 4.094 & -.038 \\
\hline e6 & $<-->$ & e12 & 6.306 & .039 \\
\hline e8 & $<-->$ & e6 & 4.289 & -.039 \\
\hline e4 & $<-->$ & e5 & 5.438 & -.038 \\
\hline e3 & $<-->$ & e14 & 8.210 & -.034 \\
\hline e2 & $<-->$ & $\mathrm{NCO}$ & 5.911 & -.064 \\
\hline $\mathrm{e} 2$ & $<-->$ & e14 & 8.455 & .041 \\
\hline e2 & $<-->$ & e7 & 4.064 & -.030 \\
\hline e1 & $<-->$ & e12 & 4.555 & -.037 \\
\hline e1 & $<-->$ & e10 & 4.734 & -.046 \\
\hline e1 & $<-->$ & e5 & 12.450 & .078 \\
\hline
\end{tabular}

Sumber : Data diolah 2020 pada lampiran 
Berdasarkan hasil modifikasi model pada tabel di atas, hasil analisis menunjukkan bahwa dengan menghubungkan error indikator el dan e, chi square menurun sebesar 12,450, sehingga dalam tahap modifikasi model ini, kedua error tersebut akan dihubungkan dengan harapan chi square model menurun dan probabilitas chi square model meningkat dan dapat melebihi 0,05 . Hasil modifikasi model dapat dilihat pada gambar berikut ini :

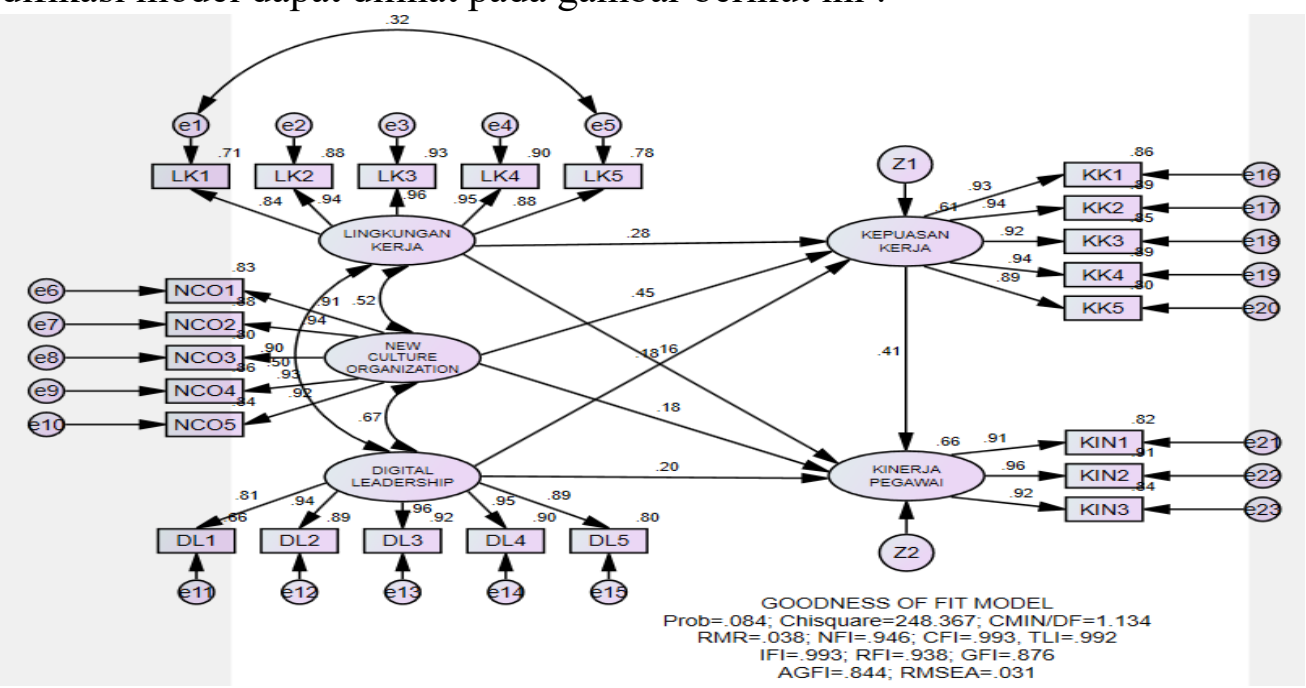

Gambar 7. Hasil Modifikasi Model

Berdasarkan hasil modifikasi model pada gambar di atas, dapat dilihat bahwa model telah memiliki goodness of fit model yang baik, probability chi square model telah meningkat dan melebihi 0,05 yaitu sebesar 0,084 sehingga model telah dapat menunjukkan kondisi populasi sebenarnya karena telah memiliki matriks kovarian yang sama dengan matriks kovarian populasi. Ringkasan hasil pengujian goodness of fit model setelah dilakukan modifikasi dapat dilihat pada tabel berikut ;

Tabel 7. Goodness of fit model setelah modifikasi

\begin{tabular}{llcl}
\hline Goodness offit index & Cut of Value & Hasil Analisis & Evaluasi Model \\
\hline $\mathrm{X}^{2}$ chi square & $<254,523$ & g. 248,367 & Good Fit \\
\hline $\begin{array}{l}\text { significancy } \\
\text { probability }\end{array}$ & $\geq 0,05$ & k. 0,084 & Good Fit \\
\hline RMSEA & $\leq 0,08$ & o. 0,031 & Good Fit \\
\hline GFI & $\geq 0,90$ & s. 0,876 & Marginal Fit \\
\hline AGFI & $\geq 0,90$ & w. 0,844 & Maginal Fit \\
\hline CMIN/DF & $\leq 2,00$ & aa. 1,134 & ' Good Fit \\
\hline TLI & $\geq 0,95$ & ee. 0,992 & Good Fit \\
\hline CFI & $\geq \geq 0,95$ & ii. 0,993 & Good Fit \\
\hline
\end{tabular}

Sumber : Data diolah (2020) pada Lampiran

Penjelasan dari masing - masing hasil uji Goodness of fit model di atas adalah sebagai berikut :

1. Chi square $\left(X^{2}\right)$

Chi Square merupakan salah satu alat uji untuk mengukur overall fit adalah likelihood ratio ChiSquare statistic. Model yang diuji akan dipandang baik atau memuaskan bila nilai Chi-Square-nya rendah dan tidak signifikan pada taraf 5\%. Semakin kecil nilai ChiSquare maka semakin baik model (Hulland dalam Ferdinand, 2000;52). Dalam penelitian ini nilai Chi-Square yang didapatkan adalah sebesar 248,367, dengan nilai $\mathrm{p}=0,084$. Oleh karena nilai chi square tidak signifikan maka dapat disimpulkan bahwa model telah memenuhi kriteria goodness of fit yang 
dipersyaratkan, model dianggap memiliki matriks kovarian yang sama dengan matriks kovarian populasi sehingga dapat menunjukkan gambaran populasi yang sebenarnya.

2. RMSEA - The Root Mean Square Error Of Approximation

RMSEA adalah alat uji lain menunjukkan goodness-of fit yang dapat diharapkan bila model diestimasi dalam populasi (Hair, et al, 1995 dalam Ferdinand, 2000;53). Nilai RMSEA yang lebih kecil atau sama dengan 0,08 merupakan indeks untuk dapat diterimanya model yang menunjukkan sebuah close fit dari model itu berdasarkan degress of freedoom (Brown \& Cudeck dalam Ferdinand, 2000). Berdasarkan penelitian ini nilai RMSEA yang didapatkan adalah sebesar 0,031. Dengan demikian model ini termasuk baik karena nilai RMSEA-nya lebih kecil dari indeks diterimanya model yaitu $0,08.3$.

3. GFI- Goodness of Fit Index

GFI adalah sebuah ukuran non-statistikal yang mempunyai rentang nilai antara 0 (poor fit) sampai dengan 1,0 (perfect fit). Nilai yang tinggi dalam indeks ini menunjukkan sebuah better fit dan suatu model dapat dikatakan very good jika nilai GFInya lebih dari atau sama dengan 0,90 (Ferdinand, 2000;54). Nilai GFI antara 0,7-0,9 dinyatakan marginal fit. Nilai GFI yang dihasilkan dalam penelitian ini adalah 0,876. Nilai ini $>0,9$ sehingga termasuk dalam kategori marginal fit.

4. AGFI- Adjusted Goodness of Fit Index

Tingkat penerimaan yang direkomendasikan adalah bila AGFI memiliki nilai sama dengan atau lebih besar dari 0,90. Nilai AGFI > 0,9 dinyatakan berada pada kriteria goodl fit. Nilai AGFI yang dihasilkan dalam penelitian ini adalah 0,844, sehingga termasuk pada kategori marginal fit.

5. CMIN/DF-The Minimum Sample Discrepancy

CMIN/DIF merupakan salah satu indikator untuk mengukur tingkat fitnya sebuah model (Ferdinand, 2000;55). Dalam hal ini CMIN/DF tidak lain adalah statistik chi-square, $\mathrm{X}^{2}$ dibagi DF-nya sehingga disebut $\mathrm{X}^{2}$ relatif. Nilai $\mathrm{X}^{2}$ relatif yang kurang dari 2.0 atau kurang dari 3.0 adalah indikasi dari acceptable fit antara model dan data (Arbuckle, 1997) dalam Ferdinand, 2000). Nilai CMIN/DF model penelitian ini adalah sebesar 1,134. Dengan demikian model ini sehingga termasuk baik karena nilai CMIN/DF-nya kurang dari 2.0.

6. TLI-Tucker Lewis Index

TLI adalah sebuah alternatif incremental fit index yang membandingkan sebuah model yang diuji terhadap sebuah baseline model (Baumgartner dan Homburg, 1996) dalam Ferdinand, 2000;57). Nilai yang sangat mendekati 1 atau lebih dari 0,95 menunjukkan a very good fit (Arbuckle, 1997) dalam Ferdinand, 2000;57). Nilai TLI yang dihasilkan dalam penelitian ini adalah 0,992. Berdasarkan kriteria TLI, maka nilai ini termasuk Pada kategori good fit.

7. CFI-Comparative Fit Index

Besaran indeks ini adalah pada rentang nilai 0 (poor fit) sampai dengan 1.0 (perfect fit). Nilai yang lebih atau sama dengan 0,95 mengindikasikan tingkat fit yang paling tinggi a very good fit (Arbuckle, 1997 dalam Ferdinand, 2000;58). Nilai CFI yang dihasilkan dalam penelitian ini adalah 0,993. Nilai ini lebih dari 0,95, sehingga termasuk pada kriteria good fit. 


\section{Pengujian Pengaruh Langsung}

Pengujian hipotesis dalam penelitian ini dilakukan berdasarkan hasil uji pengaruh langsung pada analisis SEM. Hipotesis yang digunakan dalam pengujian ini menggunakan uji hipotesis satu arah (one tail), sehingga hipotesis akan diterima jika value $<0,05$ dan Critical Ratio (CR) $>1,96$ dan Hipotesis penelitian tidak terbukti jika $p$ value $>0,05$ dan $\mathrm{CR}<1,96$.

Berikut ini adalah hasil analisis SEM sebagai acuan dalam pengujian hipotesis dalam penelitian ini :

Tabel 8. Hasil Analisis SEM untuk Pengujian Hipotesis Regression Weights: (Group number 1 - Default model)

\begin{tabular}{|c|c|c|c|c|c|}
\hline & Estimate & S.E. & C.R. & $\mathrm{P}$ & Label \\
\hline KK <--- LK & .354 & .090 & 3.913 & $* * *$ & par_19 \\
\hline $\mathrm{KK}<---\quad \mathrm{NCO}$ & .473 & .087 & 5.411 & $* * *$ & par_20 \\
\hline KK <--- $\quad$ DL & .209 & .091 & 2.297 & .022 & par_21 \\
\hline KP <--- LK & .181 & .081 & 2.241 & .025 & par_22 \\
\hline $\mathrm{KP}<---\mathrm{NCO}$ & .171 & .082 & 2.072 & .038 & par_23 \\
\hline $\mathrm{KP}<---\quad \mathrm{DL}$ & .200 & .080 & 2.510 & .012 & par_24 \\
\hline $\mathrm{KP}<---\mathrm{KK}$ & .367 & .082 & 4.488 & $* * *$ & par_25 \\
\hline
\end{tabular}

Berdasarkan hasil analisis SEM pada tabel di atas, diperoleh beberapa hasil sebagai berikut : Nilai $p$ value pengaruh variabel lingkungan kerja terhadap kepuasan kerja (LK $\rightarrow \mathrm{KK}$ ) sangat signifikan $(* * *)$ dengan cr sebesar 3,913. Oleh karena nilai $\mathrm{p}$ value yang diperoleh $<0,05$ dan $\mathrm{cr}$ bertanda positif $>1,96$ maka disimpulkan bahwa lingkungan kerja berpengaruh positif dan signifikan terhadap kepuasan kerja, semakin baik lingkungan kerja maka semakin tinggi kepuasan kerja pegawai.

Nilai $p$ value pengaruh variabel new culture organization terhadap kepuasan kerja (NCO $\rightarrow \mathrm{KK}$ ) sangat signifikan $(* * *)$ dengan cr sebesar 5,411 . Oleh karena nilai $\mathrm{p}$ value yang diperoleh $<0,05$ dan cr bertanda positif $>1,96$ maka disimpulkan bahwa new culture organization berpengaruh positif dan signifikan terhadap kepuasan kerja, semakin baik lingkungan kerja maka semakin tinggi kepuasan kerja pegawai.

Nilai $\mathrm{p}$ value pengaruh variabel digital leadership terhadap kepuasan kerja (DL $\rightarrow \mathrm{KK}$ ) sangat signifikan $(0,022)$ dengan cr sebesar 2,297 . Oleh karena nilai $p$ value yang diperoleh $<0,05$ dan $\mathrm{cr}$ bertanda positif $>1,96$ maka disimpulkan bahwa digital leadership berpengaruh positif dan signifikan terhadap kepuasan kerja, semakin baik digital leadership maka semakin tinggi kepuasan kerja pegawai.

Nilai $p$ value pengaruh variabel lingkungan kerja terhadap kinerja pegawai $(\mathrm{LK} \rightarrow \mathrm{KP})$ signifikan $(0,025)$ dengan cr sebesar 2,241 . Oleh karena nilai $p$ value yang diperoleh $<0,05$ dan cr bertanda positif $>1,96$ maka disimpulkan bahwa lingkungan kerja berpengaruh positif dan signifikan terhadap kinerja pegawai, semakin baik lingkungan kerja maka semakin tinggi kinerja pegawai pegawai.

Nilai p value pengaruh variabel new culture organization terhadap kinerja pegawai (NCO $\rightarrow \mathrm{KP})$ signifikan $(0,038)$ dengan cr sebesar 2,072 . Oleh karena nilai $\mathrm{p}$ value yang diperoleh $<0,05$ dan $\mathrm{cr}$ bertanda positif $>1,96$ maka disimpulkan bahwa new culture organization berpengaruh positif 
dan signifikan terhadap kinerja pegawai, semakin baik lingkungan kerja maka semakin tinggi kinerja pegawai pegawai.

Nilai $\mathrm{p}$ value pengaruh variabel digital leadership terhadap kinerja pegawai (DL $\rightarrow \mathrm{KP}$ ) signifikan $(0,012)$ dengan cr sebesar 2,510 . Oleh karena nilai $\mathrm{p}$ value yang diperoleh $<0,05$ dan $\mathrm{cr}$ bertanda positif $>1,96$ maka disimpulkan bahwa digital leadership berpengaruh positif dan signifikan terhadap kinerja pegawai, semakin baik digital leadership maka semakin tinggi kinerja pegawai pegawai.

Nilai $\mathrm{p}$ value pengaruh variabel kepuasan kerja terhadap kinerja pegawai $(\mathrm{KK} \rightarrow \mathrm{KP})$ sangat signifikan $(* * *)$ dengan cr sebesar 4,488 . Oleh karena nilai $\mathrm{p}$ value yang diperoleh $<0,05$ dan $\mathrm{cr}$ bertanda positif $>1,96$ maka disimpulkan bahwa kepuasan kerja pegawai berpengaruh positif dan signifikan terhadap kinerja pegawai, semakin tinggi kepuasan kerja pegawai maka semakin tinggi kinerja pegawai pegawai.

\section{Koefisien Determinasi}

Dalam analisis SEM, koefisien determinasi menunjukkan besar pengaruh seluruh variabel eksogen terhadap variabel endogen. Koefisien determinasi ini dilihat dari nilai squared multiple correlation.

Tabel 9. Koefisien Determinasi Squared Multiple Correlations: (Group number 1 - Default model)

\begin{tabular}{cc}
\hline Variabel Endogen & Estimate \\
\hline Kepuasan Kerja & 0,606 \\
\hline Kinerja Pegawai & 0,661 \\
\hline
\end{tabular}

Sumber : Data diolah 2020 pada Lampiran

Berdasarkan hasil analisis pada tabel di atas, hasil analisis menunjukkan bahwa nilai squared multiple correlation variabel kepuasan kerja adalah sebesar 0,606, hal ini menunjukkan bahwa besar kontribusi yang diberikan variabel lingkungan kerja, new culture organization dan digital leadership terhadap kepuasan kerja pegawai adalah sebesar 60,6\%, sedangkan sisanya sebesar $39,4 \%$ variansi kepuasan kerja dipengaruhi oleh faktor lain di luar lingkungan kerja, new culture organization, digital leadership dan kepuasan kerja.

Selanjutnya, pada variabel kinerja pegawai, nilai squared dmultiple correlation yang diperoleh adalah sebesar 0,661. Hal ini menunjukkan bahwa besar pengaruh lingkungan kerja, new culture organization, digital leadership dan kepuasan kerja terhadap kinerja pegawai adalah sebesar $66,1 \%$, sedangkan sisanya sebesar 33,9\% variansi kinerja pegawai dipengaruhi faktor lain di luar lingkungan kerja, new culture organization, digital leadership dan kepuasan kerja pegawai.

\section{Pengaruh Tidak Langsung}

Dalam penelitian ini, kepuasan kerja berperan sebagai variabel yang memediasi pengaruh tidak langsung lingkungan kerja, new culture organization, digital leadership dan kepuasan kerja terhadap kinerja pegawai. Untuk menguji peran kepuasan kerja dalam memediasi pengaruh tidak langsung lingkungan kerja, new culture organization, digital leadership dan kepuasan kerja terhadap kinerja pegawai maka dilakukan uji Sobel.

Pengujian Peran kepuasan kerja dalam memediasi pengaruh tidak langsung lingkungan kerja terhadap kinerja

Hipotesis yang digunakan dalam pengujian ini adalah :

Ho : kepuasan kerja tidak dapat memediasi pengaruh tidak langsung variabel lingkungan kerja terhadap kinerja pegawai 
$\mathrm{Ha}$ : kepuasan kerja dapat memediasi pengaruh tidak langsung variabel lingkungan kerja terhadap kinerja pegawai

Dengan taraf signifikansi 5\%, maka Ho akan ditolak jika hasil pengujian efek mediasi one tail $<$ 0,05 dan Ho tidak ditolak jika hasil pengujian efek mediasi one tail $>0,05$.

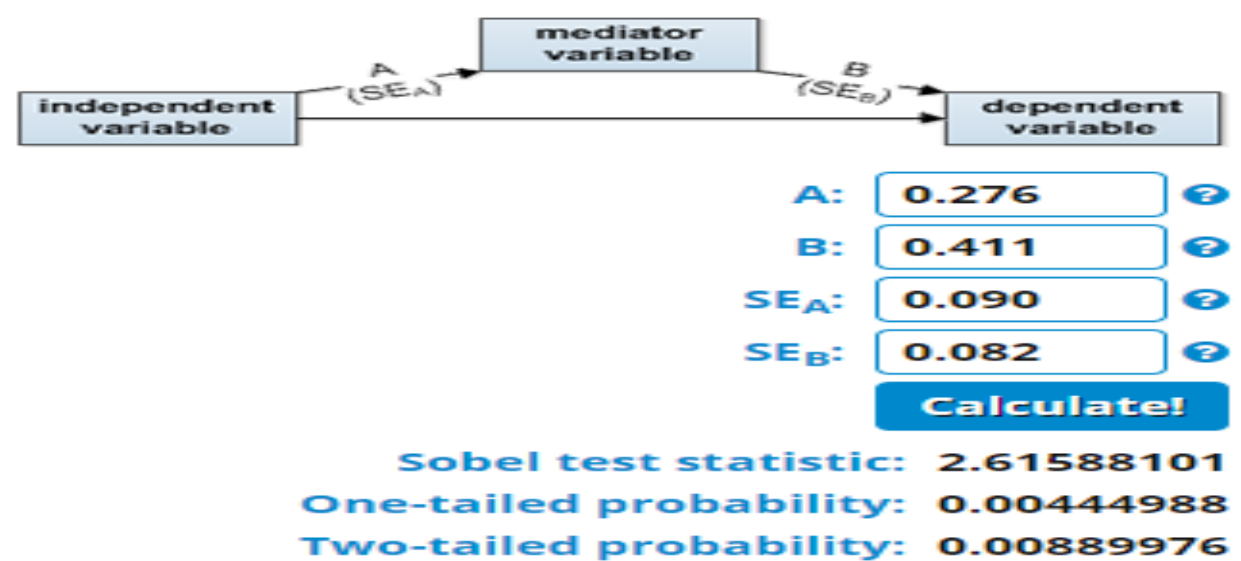

\section{Gambar 8. Hasil Uji Sobel Efek Mediasi Kepuasan kerja pada pengaruh lingkungan kerja} terhadap kinerja pegawai

Berdasarkan hasil uji Sobel pada gambar di atas, diperoleh nilai $\mathrm{p}$ value two tail sebesar $0,00889976 \sim 0,0089$, oleh karena nilai $\mathrm{p}$ value $<0,05$ maka Ho ditolak dan disimpulkan bahwa kepuasan kerja dapat memediasi pengaruh tidak langsung lingkungan kerja terhadap kinerja pegawai. Hal ini menunjukkan bahwa lingkungan kerja yang baik akan meningkatkan kepuasan kerja pegawai yang selanjutnya akan meningkatkan kinerja pegawai. Sifat mediasi kepuasan kerja pada pengaruh lingkungan kerja terhadap kinerja pegawai ini adalah bersifat parsial (partial mediation), hal ini karena berdasarkan hasil analisis SEM, tanpa adanya mediasi dari kepuasan kerja, lingkungan kerja dapat berpengaruh secara langsung terhadap kinerja pegawai. Pengujian Peran kepuasan kerja dalam memediasi pengaruh tidak langsung new culture organization terhadap kinerja

Hipotesis yang digunakan dalam pengujian ini adalah :

Ho : kepuasan kerja tidak dapat memediasi pengaruh tidak langsung variabel new culture organization terhadap kinerja pegawai

$\mathrm{Ha}$ : kepuasan kerja dapat memediasi pengaruh tidak langsung variabel new culture organization terhadap kinerja pegawai

Dengan taraf signifikansi 5\%, maka Ho akan ditolak jika hasil pengujian efek mediasi two tail $<$ 0,05 dan Ho tidak ditolak jika hasil pengujian efek mediasi two tail $>0,05$. 


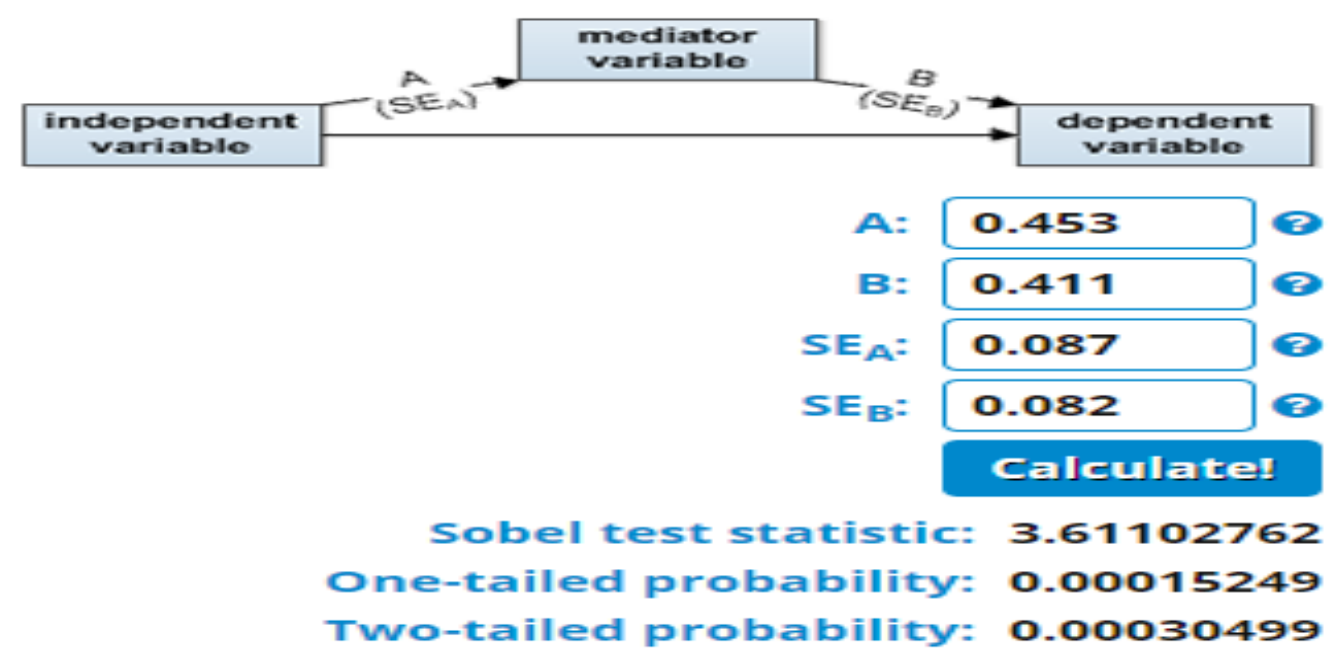

\section{Gambar 9. Hasil Uji Sobel Efek Mediasi Kepuasan kerja pada pengaruh new culture organization terhadap kinerja pegawai}

Berdasarkan hasil uji Sobel pada gambar di atas, diperoleh nilai $\mathrm{p}$ value two tail sebesar $0,00015249 \sim 0,00015$, oleh karena nilai $\mathrm{p}$ value $<0,05$ maka Ho ditolak dan disimpulkan bahwa kepuasan kerja dapat memediasi pengaruh tidak langsung new culture organization terhadap kinerja pegawai. Hal ini menunjukkan bahwa new culture organization yang baik akan meningkatkan kepuasan kerja pegawai yang selanjutnya akan meningkatkan kinerja pegawai. Sifat mediasi kepuasan kerja pada pengaruh new culture organization terhadap kinerja pegawai ini adalah bersifat parsial (partial mediation), hal ini karena berdasarkan hasil analisis SEM, tanpa adanya mediasi dari kepuasan kerja, new culture organization dapat berpengaruh secara langsung terhadap kinerja pegawai.

Pengujian Peran kepuasan kerja dalam memediasi pengaruh tidak langsung digital leadership terhadap kinerja

Hipotesis yang digunakan dalam pengujian ini adalah :

Ho : kepuasan kerja tidak dapat memediasi pengaruh tidak langsung variabel digital leadership terhadap kinerja pegawai

Ha : kepuasan kerja dapat memediasi pengaruh tidak langsung variabel digital leadership terhadap kinerja pegawai

Dengan taraf signifikansi 5\%, maka Ho akan ditolak jika hasil pengujian efek mediasi two tail $<$ 0,05 dan Ho tidak ditolak jika hasil pengujian efek mediasi two tail $>0,05$. 


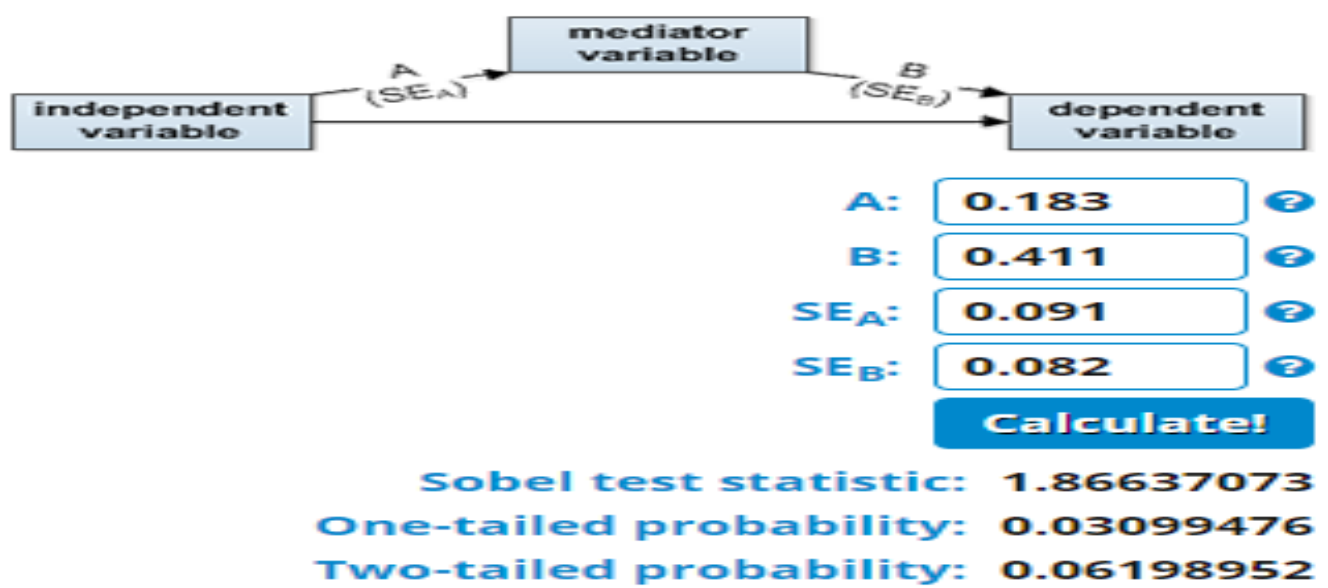

\section{Gambar 10. Hasil Uji Sobel Efek Mediasi Kepuasan kerja pada pengaruh digital leadership terhadap kinerja pegawai}

Berdasarkan hasil uji Sobel pada gambar di atas, diperoleh nilai $\mathrm{p}$ value two tail sebesar 0,03099476 0,03099, oleh karena nilai $\mathrm{p}$ value $<0,05$ maka Ho ditolak dan disimpulkan bahwa kepuasan kerja dapat memediasi pengaruh tidak langsung digital leadership terhadap kinerja pegawai. Hal ini menunjukkan bahwa digital leadership yang baik akan meningkatkan kepuasan kerja pegawai yang selanjutnya akan meningkatkan kinerja pegawai. Sifat mediasi kepuasan kerja pada pengaruh digital leadership terhadap kinerja pegawai ini adalah bersifat parsial (partial mediation), hal ini karena berdasarkan hasil analisis SEM, tanpa adanya mediasi dari kepuasan kerja, digital leadership dapat berpengaruh secara langsung terhadap kinerja pegawai.

\section{PEMBAHASAN}

\section{Pengaruh Lingkungan Kerja Terhadap Kinerja Pegawai}

Hipotesis 1 dalam penelitian ini menyatakan bahwa lingkungan kerja berpengaruh terhadap kinerja pegawai. Berdasarkan hasil analisis SEM dalam penelitian ini, nilai $\mathrm{p}$ value pengaruh variabel lingkungan kerja terhadap kinerja pegawai (LK $\rightarrow$ KP) signifikan $(0,025)$ dengan cr sebesar 2,241. Oleh karena nilai $\mathrm{p}$ value yang diperoleh $<0,05$ dan cr bertanda positif $>1,96$ maka disimpulkan bahwa lingkungan kerja berpengaruh positif dan signifikan terhadap kinerja pegawai, semakin baik lingkungan kerja maka semakin tinggi kinerja pegawai pegawai. Hal ini mendukung hipotesis 1 dalam penelitian ini sehingga hipotesis 1 diterima.

\section{Pengaruh New Culture Organization Terhadap Kinerja Pegawai}

Hipotesis 2 dalam penelitian ini menyatakan bahwa new culture organization berpengaruh terhadap kinerja pegawai. Berdasarkan hasil analisis SEM dalam penelitian ini, nilai $\mathrm{p}$ value pengaruh variabel new culture organization terhadap kinerja pegawai (NCO $\rightarrow \mathrm{KP}$ ) signifikan $(0,038)$ dengan cr sebesar 2,072 . Oleh karena nilai $\mathrm{p}$ value yang diperoleh $<0,05$ dan cr bertanda positif $>1,96$ maka disimpulkan bahwa new culture organization berpengaruh positif dan signifikan terhadap kinerja pegawai, semakin baik lingkungan kerja maka semakin tinggi kinerja pegawai pegawai. . Hal ini mendukung hipotesis 2 dalam penelitian ini sehingga hipotesis 2 diterima. 


\section{Pengaruh Digital Leadership Terhadap Kinerja Pegawai}

Hipotesis 3 dalam penelitian ini menyatakan bahwa digital leadership berpengaruh terhadap kinerja pegawai. Berdasarkan hasil analisis SEM dalam penelitian ini, nilai $\mathrm{p}$ value pengaruh variabel digital leadership terhadap kinerja pegawai (DL $\rightarrow$ KP) signifikan $(0,012)$ dengan $\mathrm{cr}$ sebesar 2,510. Oleh karena nilai $p$ value yang diperoleh $<0,05$ dan cr bertanda positif $>1,96$ maka disimpulkan bahwa digital leadership berpengaruh positif dan signifikan terhadap kinerja pegawai, semakin baik digital leadership maka semakin tinggi kinerja pegawai pegawai. Hal ini mendukung hipotesis 3 dalam penelitian ini sehingga hipoetsis 3 diterima.

\section{Pengaruh Lingkungan Kerja Terhadap Kepuasan Kerja}

Hipotesis 4 dalam penelitian ini menyatakan bahwa lingkungan kerja berpengaruh terhadap kepuasan kerja pegawai. Berdasarkan hasil analisis SEM dalam penelitian ini, nilai p value pengaruh variabel lingkungan kerja terhadap kepuasan kerja (LK $\rightarrow \mathrm{KK})$ sangat signifikan (***) dengan cr sebesar 3,913. Oleh karena nilai $p$ value yang diperoleh $<0,05$ dan cr bertanda positif $>$ 1,96 maka disimpulkan bahwa lingkungan kerja berpengaruh positif dan signifikan terhadap kepuasan kerja, semakin baik lingkungan kerja maka semakin tinggi kepuasan kerja pegawai. Hal ini mendukung hipotesis 4 dalam penelitian ini sehingga hipoetsis 4 diterima.

\section{Pengaruh New Culture Organization Terhadap Kepuasan Kerja}

Hipotesis 5 dalam penelitian ini menyatakan bahwa new culture organization berpengaruh terhadap kepuasan kerja pegawai. Berdasarkan hasil analisis SEM dalam penelitian ini, nilai $\mathrm{p}$ value pengaruh variabel new culture organization terhadap kepuasan kerja (NCO $\rightarrow \mathrm{KK}$ ) sangat signifikan $(* * *)$ dengan cr sebesar 5,411. Oleh karena nilai $\mathrm{p}$ value yang diperoleh $<0,05$ dan $\mathrm{cr}$ bertanda positif $>1,96$ maka disimpulkan bahwa new culture organization berpengaruh positif dan signifikan terhadap kepuasan kerja, semakin baik lingkungan kerja maka semakin tinggi kepuasan kerja pegawai. Hal ini mendukung hipotesis 5 dalam penelitian ini sehingga hipoetsis 5 diterima.

\section{Pengaruh Digital Leadership Terhadap Kepuasan Kerja}

Hipotesis 6 dalam penelitian ini menyatakan bahwa digital leadership berpengaruh terhadap kepuasan kerja pegawai. Berdasarkan hasil analisis SEM dalam penelitian ini, nilai p value pengaruh variabel digital leadership terhadap kepuasan kerja (DL $\rightarrow \mathrm{KK}$ ) sangat signifikan $(0,022)$ dengan cr sebesar 2,297. Oleh karena nilai $p$ value yang diperoleh $<0,05$ dan cr bertanda positif $>1,96$ maka disimpulkan bahwa digital leadership berpengaruh positif dan signifikan terhadap kepuasan kerja, semakin baik digital leadership maka semakin tinggi kepuasan kerja pegawai. Hal ini mendukung hipotesis 6 dalam penelitian ini sehingga hipoetsis 6 diterima.

\section{Pengaruh Kepuasan Kerja Terhadap Kinerja Pegawai}

Hipotesis 7 dalam penelitian ini menyatakan bahwa kepuasan kerja berpengaruh terhadap kinerja kerja pegawai. Berdasarkan hasil analisis SEM dalam penelitian ini, nilai $\mathrm{p}$ value pengaruh variabel kepuasan kerja terhadap kinerja pegawai $(\mathrm{KK} \rightarrow \mathrm{KP})$ sangat signifikan (***) dengan $\mathrm{cr}$ sebesar 4,488. Oleh karena nilai $p$ value yang diperoleh $<0,05$ dan cr bertanda positif $>1,96$ maka disimpulkan bahwa kepuasan kerja pegawai berpengaruh positif dan signifikan terhadap kinerja pegawai, semakin tinggi kepuasan kerja pegawai maka semakin tinggi kinerja pegawai pegawai. Hal ini mendukung hipotesis 7 dalam penelitian ini sehingga hipoetsis 7 diterima. 


\section{KESIMPULAN DAN SARAN}

Berdasarkan hasil analisis dan pembahasan diatas, maka dapat disimpulkan bahwa; (1) lingkungan kerja memiliki pengaruh yang positif dan signifikan terhadap kinerja pegawai, (2) new culture organization memiliki pengaruh yang positif dan signifikan terhadap kinerja pegawai, (3) digital leadership memiliki pengaruh yang positif dan signifikan terhadap kinerja pegawai, (4) lingkungan kerja berpengaruh positif dan signifikan terhadap kinerja pegawai dengan kepuasan kerja sebagai variabel intervening, (5) new culture organization berpengaruh positif dan signifikan terhadap kinerja pegawai dengan kepuasan kerja sebagai variabel intervening, (6) digital leadership berpengaruh positif dan signifikan terhadap kinerja pegawai dengan kepuasan konsumen sebagai variabel intervening, dan (7) kepuasan kerja memiliki pengaruh yang positif dan signifikan terhadap kinerja pegawai

Saran yang diberikan berdasarkan hasil penelitian ini diharapkan dapat dijadikan acuan oleh pimpinan pada Dinas Perindustrian dan Tenaga Kerja dalam menyikapi bagaimana kinerja pegawai untuk dapat meningkatkan pelayanan dan stigma negatif dari masyarakat untuk pegawai Dinas.

\section{DAFTAR PUSTAKA}

Alas, R., Übius, U., Lorents, P., \& Matsak, E. (2017). Corporate Social Responsibility In European And Asian Countries. Jurnal Manajemen Bisnis Dan Inovasi (JMBI) UNSRAT Vol. 4 No. 1

Astuti, W. (2008). Pengaruh Perilaku Kepemimpinan pada kinerja Pegawai Dinas Tata Kota Pekanbaru. Jurnal Ilmu Administrasi Negara, 8(2): h:73-82.

Bass, B.M. (1997). Does the transactional-transformational leadership paradigm transcend organisational and national boundaries. American Psychologist, 52(2), pp.130-9

Brahmasari dan Suprayetno. (2008). Pengaruh motivasi Kerja, Kepemimpinan dan Budaya Organisasi Terhadap Kepuasan Kerja Karyawan serta Dampaknya Pada Kinerja Perusahaan (Studi Kasus Pada PT Pei Hai Interbasional Wiratama Indonesia)

Badeni (2013). Kepemimpinan dan Perilaku Organisasi, Penerbit: CV. Alfabeta, Bandung.

Dhermawan, A.A.N.B., Sudibya, I.G.A., dan Utama, I.W.M. (2012). Pengaruh Motivasi, Lingkungan Kerja, Kompensasi, dan Kompensasi terhadap Kepuasan Kerja dan Kinerja Pegawai di Lingkungan Kantor Dinas Pekerjaan Umum Provinsi Bali. Jurnal Manajemen, Strategi Bisnis, dan Kewirausahaan.

Robbins, S.P. (2002). Prinsip-prinsip Perilaku Organisasi. Jakarta: Erlangga

Dhino, S.R. (2015). Pengaruh Kepuasan Kerja, Kompensasi, Motivasi Kerja, dan Komitmen Organisasi terhadap Kinerja Karyawan Dinas Sosial Tenaga Kerja Sumatera Barat. Skripsi. Fakutas Ekonomi Universitas Bung Hatta. 
M. Hanif Al Rizal. (2012).Pengaruh Budaya Organisasi Dan Kepuasan Kerja Terhadap Kinerja Karyawan(Studi Pada Rumah Sakit Panti Wilasa“Citarum” Kota Semarang)

Mangkunegara, A.A. Anwar Prabu. 2014. Evaluasi Kinerja SDM. Bandung. Penerbit Refika Aditama.

Mawei, A.C., Nelwan, O., dan Uhing, Y. (2014). Kepemimpinan, Penempatan Kerja dan Kompensasi Pengaruhnya terhadap Kepuasan Kerja pada PT. Bank BNI (Persero), Tbk KCU Manado. Jurnal EMBA. 2(2), pp944- 95

Lambey, B., Lengkong, V.P.K., Wenas, R.S. (2020). Pengaruh Penempatan Pegawai Serta Budaya Kerja Terhadap Kinerja Pegawai Dengan Kepuasan Kerja Sebagai Variable Intervening Di PT PLN (Persero) UIP SULBAGUT, Jurnal Manajemen Bisnis Dan Inovasi (JMBI) UNSRAT 7(3), pp394-406

Mojambo, G. A., Tulung, J. E., \& Saerang, R. T. (2020). The Influence of Top Management Team (TMT) Characteristics Toward Indonesian Banks Financial Performance During The Digital Era (2014-2018). JMBI UNSRAT (Jurnal Ilmiah Manajemen Bisnis dan Inovasi Universitas Sam Ratulangi)., 7(1).

Nitisimeto, A.S. (2004). Manajemen Personalia. Cetakan Ketujuh, Ghalia Indonesia, Jakarta.

Putri, I.S. (2016). Pengaruh Budaya Organisasi terhadap Kinerja Pegawai di Dinas Pendidikan dan Kebudayaan Kota Samarinda. eJournal Administrasi Negara, 4(4).

Robbins, S.P. (2002). Prinsip-prinsip Perilaku Organisasi. Jakarta: Erlangga

Rivai, V., dan Mulyadi, D. (2012). Kepemimpinan dan Perilaku Organisasi, Edisi Ketiga, Cetakan Kesembilan, Penerbit: PT. RajaGrafindo Persada, Bandung.

Sarwoto.(2011). Dasar-Dasar Organisasi dan Manajemen. Jakarta: Gahlia Indonesia.

Schein, E.H. (2011). Organizational culture and leadership. San Fransisco: Jossey-Bass.

Sedarmayanti. (2012). Manajemen Sumber Daya Manusia. Bandung: CV Mandar Maju

Siagian, P. S. (2012).Teori dan Praktek Kepemimpinan, cetakan Kelima Jakarta: Rineka Cipta.

Sudarmanto. (2012). Kinerja dan Pengembangan Kompetensi SDM (Teori, Dimensi Pengukuran dan Implementasi dalam Organisasi). Yogyakarta : Pustaka Pelajar

Sutrisno, Edy, 2009, Manajemen Sumber Daya Manusia, Penerbit Kencana Prenada Media Group, Jakarta. 